\title{
Differences of Cyberloafing Behavior Outcomes on Men and Women Employees
}

\author{
Rauly Sijabat \\ Program Studi Manajemen, Universitas PGRI Semarang, Semarang, Indonesia \\ *Email: raulysijabat@ upgris.ac.id
}

\begin{abstract}
The activities of reading news, chatting, viewing YouTube and Facebook or even status updates, Instagram, buying and selling online, to playing online games that are not related to work by using internet facilities are cyberloafing behaviors that are often carried out by employees. The limitations of previous research examining the impact of cyberloafing on work behavior empirically are still very limited. In addition, previous research that explains the occurrence of cyberloafing behavior also shows results that have not been established. Encouraged by these findings, this study aimed to examine the factors that explain cyberloafing behavior and its impact on employees' organizational behavior. To meet these objectives, an empirical model was developed with job characteristics and self-control variables as exogenous variables, job stress and cyberloafing as mediating variables and laziness as endogenous variables. Testing the influence between these variables was carried out with an analytical approach to Structural Equation Modeling (SEM) which used empirical data obtained through questionnaires as an interview guide to employee respondents in various fields of work. The results of data analysis showed that job characteristics, self control, and job stress were statistically proven to have an effect on cyberloafing behavior. Cyberloafing testing on negative organizational behavior, namely laziness also shows a real influence. In addition, the results of this study also show that there are differences in prevalence caused by cyberloafing behavior between male and female employees.
\end{abstract}

Keywords: Cyberloafing; Job Characteristics; Laziness; Self Control

\section{Introduction}

Surfing in cyberspace such as reading news, chatting, watching YouTube and Facebook or even updating status, Instagram, online buying and selling, and playing online games is an activity that has absolutely nothing to do with work in the office but is often carried out by employees on the sidelines of office hours. It can be done by using private internet facilities or using WiFi provided by the company. This behavior is called cyberloafing.

Cyberloafing is a phenomenon of new organizational behavior along with the digitization that goes into all sides of life including at work. Cyberloafing behavior can have both positive and negative implications. The positive implication of cyberloafing behavior according to Lynn, Coker \& Coker (2011) is if it is done no more than $12 \%$ of all work time. Positive implications of cyberloafing behavior are increasing awareness of developing information (Seymour \& Nadasen, 2007; Lynn et al, 2011), increasing employee creativity, increasing employee well-being, recreation and recovery solutions for employees (Malhotra, 2013). Balancing life work and personal employees, reducing work stress and workload, and making life more interesting (Anandarajan, Paravastu \& Simmers, 2006; Lim \& Chen, 2012). Some studies also showed that cyberloafing behavior also leads to counterproductive behavior (Lim, 2002; Lim \& Teo, 2005). As productivity declines (Griffiths, 2010; Weatherbee, 2010; Liberman, Seidman, McKenna, \& Buffardi, 2011; Malhotra, 2013), increases in corporate finances, indisciplinary behavior, threats to corporate information security (Lim, 2002; Lim \& Teo, 2005; Ozler \& Polat, 2012; Malhotra, 2013).

The emergence of cyberloafing behavior can be triggered by individual employee factors (Liberman, Seidman \& McKenna, 2011; Ozler \& Polat, 2012; Malhotra, 2013; Abidin et al, 2014) and organizational factors (Ozler \& Polat, 2012; Al-Shuaibi, \& Shamsudin, 2013; Malhotra, 2013). One individual factor that can explain cyberloafing behavior is self-control (Ozler, \& Polat, 2012). Self-control is related to the ability of 
employees to hold desires that are contrary to the norms prevailing in the company. Empirically, the effect of self-control on cyberloafing behavior has been investigated by Ramadan \& Sari (2018). The results of the study showed a significant positive relationship between self-control variables on cyberloafing behavior. Still on testing the same variable, a study conducted by Sari \& Ratnaningsih (2018) showed a significant negative effect of self-control on cyberloafing behavior while organizational factors focus on the work characteristics variable from the study of Malhotra (2013) and Ozler \& Polat (2012) which have not been empirically tested in this study.

Although there have been many studies related to cyberloafing behavior, empirical studies are still limited to determinants of cyberloafing behavior. Studies that map aspects of cyberloafing behavior and empirical testing have not been conducted. Referring to these findings, this study aims to develop a comprehensive model of cyberloafing behavior by testing the determinants and outcomes of cyberloafing behavior and mapping the preferences of cyberloafing behavior according to gender.

\section{References and Research Models}

\section{Cyberloafing Behavior}

Lim (2002) conceptualized cyberloafing behavior is as an activity carried out by employees to intentionally utilize internet access provided by the company to carry out actions that do not relate to work during working hours. By Blanchard \& Henle (2008), cyberloafing behavior is categorized into two groups, namely minor cyberloafing and serious cyberloafing. Minor cyberloafing behavior includes using the internet and accessing email that is done during working hours such as receiving and sending private messages, visiting news sites, sports, and finance while serious cyberloafing behavior includes gambling online, downloading songs, or just opening or even watching online movie sites.

\section{Cyberloafing Based on Gender}

Lim and Chen (2009) stated that there are differences in internet usage preferences according to gender. There are indications of the frequency, intensity, and nature of internet use by gender. As stated by Rahman \& AbdulGader (1993), Anandarajan, Simmers, \& Igbaria (2000), Ono \& Zavodny (2003), Colley \& Maltby (2008), Garrett \& Danziger (2008) that the emergence of differences in preferences is caused by differences in preferences in the purpose of using the internet.

\section{Determinants of Cyberloafing}

Determinants of cyberloafing behavior by Ozler \& Polat (2012) and Malhotra (2013) are categorized in individual and organizational factors. Individual factors includes relating to individual perceptions and attitudes towards internet use, demographic characteristics, personality, self-control, selfefficacy, locus of control. Organizational factors include restrictions on internet use, job characteristics, manager support, and applicable norms.

\section{Work Stress}

Work stress by Salleh, Bakar and Keong (2008) is interpreted as a pressure, strength or a tendency or a mental effort made by someone against their work. According to Robbins and Judge (2008), there are three categories of symptoms that appear to a person who is experiencing work stress, namely physical function disorder, psychological function disorder, and behavior disorder.

A study conducted by Kusumawati \& Fransiska (2018) found that work stress proved to have a positive but not significant effect in explaining cyberloafing behavior. However, the effect of work stress on cyberloafing behavior in a study conducted by Koay, Soh \& Chew (2017) showed significant positive results.

\section{Self-Control}

Self-control according to Baumeister (2002) is conceptualized as the ability possessed by individuals to direct and regulate the feelings, thoughts and behavior needed in order to adapt to the environment or to meet certain needs or other temptations. Selfcontrol is a determinant of cyberloafing behavior that comes from individuals (Ozler \& Polat, 2012). Good self-control is thought to be needed to minimize cyberloafing behavior by employees. With good self- 
control, employees are able to restrain themselves from acting that is not in accordance with the norms at work which in this case is an act of cyberloafing.

\section{Job Characteristics}

Ozler \& Polat (2012) in their study stated that job characteristics are an explanation of cyberloafing behavior at the organizational level. Arshad \& Bukhari (2016) in their study measured job characteristics in five aspects, namely skill variety, task identity, task significance, autonomy and feedback on

Table 1. Reviews of Previous Study

\begin{tabular}{|c|c|c|c|}
\hline Research Sources & Independent Variables & $\begin{array}{c}\text { Dependent } \\
\text { Variables }\end{array}$ & Findings \\
\hline $\begin{array}{l}\text { Garrett, R Kelly \& } \\
\text { James N Danziger } \\
(2008)\end{array}$ & $\begin{array}{l}\text { Difference in intensity of } \\
\text { personal internet usage } \\
\text { based on: } \\
\text { - } \quad \text { Lower-upper } \\
\text { occupational groups } \\
\text { - } \quad \text { Job autonomy level } \\
\text { - } \quad \text { Income level } \\
\text { - } \quad \text { Educational level } \\
\text { - } \quad \text { Male-female personal } \\
\text { - } \quad \text { Male-female leisure } \\
\text { - } \quad \text { Male-female } \\
\quad \text { communication }\end{array}$ & $\begin{array}{l}\text { Men proved to use } \\
\text { the internet more } \\
\text { for personal gain } \\
\text { than women. }\end{array}$ & $\begin{array}{l}\text { Garrett, R Kelly \& James N } \\
\text { Danziger (2008) }\end{array}$ \\
\hline $\begin{array}{l}\text { Ramadhan, Vian } \\
\text { Arsita \& Erita } \\
\text { Yuliaseti Diah Sari } \\
(2018)\end{array}$ & Self-control & $\begin{array}{l}\text { Cyberloafing } \\
\text { Behavior }\end{array}$ & $\begin{array}{l}\text { Self-control had a significant } \\
\text { positive relationship with } \\
\text { cyberloafing behavior }\end{array}$ \\
\hline $\begin{array}{l}\text { Sari, Suci Laria \& } \\
\text { Ika Zenita } \\
\text { Ratnaningsih (2018) }\end{array}$ & Self-control & $\begin{array}{l}\text { Cyberloafing } \\
\text { Behavior }\end{array}$ & $\begin{array}{l}\text { Self-control had a significant } \\
\text { negative effect on cyberloafing } \\
\text { behavior }\end{array}$ \\
\hline $\begin{array}{l}\text { Ardilasari, Noratika } \\
\text { \& Ari Firmanto } \\
(2017)\end{array}$ & Self-control & $\begin{array}{l}\text { Cyberloafing } \\
\text { Behavior }\end{array}$ & $\begin{array}{l}\text { Self-control had a significant } \\
\text { negative effect on cyberloafing } \\
\text { behavior }\end{array}$ \\
\hline $\begin{array}{l}\text { Kusumawati, Aqsa } \\
\text { \& Rosaly Fransiska } \\
(2018)\end{array}$ & $\begin{array}{ll}\text { - } & \text { Work family conflict } \\
\text { - } & \text { Work stress }\end{array}$ & $\begin{array}{l}\text { Cyberloafing } \\
\text { Behavior }\end{array}$ & $\begin{array}{l}\text { Work stress had a positive } \\
\text { effect but Not significant on } \\
\text { cyberloafing behavior }\end{array}$ \\
\hline $\begin{array}{l}\text { Koay, Kian Yeik., } \\
\text { Patrick Chin-Hooi } \\
\text { Soh \& Kok Wai } \\
\text { Chew (2017) }\end{array}$ & $\begin{array}{ll}\text { - } & \text { Private demands } \\
\text { - } & \text { Stress kerja }\end{array}$ & $\begin{array}{l}\text { Cyberloafing } \\
\text { Behavior }\end{array}$ & $\begin{array}{l}\text { Work stress had a significant } \\
\text { positive effect on cyberloafing } \\
\text { behavior }\end{array}$ \\
\hline $\begin{array}{l}\text { Arshad, Aftab \& } \\
\text { Bukhari (2016) }\end{array}$ & $\begin{array}{l}\text { Job characteristic: } \\
\text { - } \quad \text { Skill variety } \\
\text { - } \quad \text { Task identity } \\
\text { - } \quad \text { Task significance } \\
\text { - }\end{array}$ & $\begin{array}{l}\text { Cyberloafing } \\
\text { Behavior }\end{array}$ & $\begin{array}{l}\text { - Skill variety and autonomy } \\
\text { had a significant negative } \\
\text { effect on cyberloafing } \\
\text { behavior } \\
\text { - Task identity had a positive } \\
\text { effect but Not significant } \\
\text { on cyberloafing behavior } \\
\text { - Task significance and } \\
\text { feedback had a negative } \\
\text { effect but Not significant } \\
\text { on cyberloafing behavior }\end{array}$ \\
\hline
\end{tabular}

cyberloafing behavior. The results of the study showed that variety and autonomy skills had a significant negative effect on cyberloafing behavior, task identity had no a significant positive effect on cyberloafing behavior, task significance and feedback had no significant negative effect on cyberloafing behavior.

\section{Cyberloafing Outcomes}

The orientation of cyberloafing can be categorized in the following four groups: (1) Development behavior. This behavior assumes that cyberloafing behavior as a potential source for learning. Cyberloafing 
behavior from this perspective is considered to be able to improve skills that are useful for future employee activities that are able to provide benefits for individuals and organizations (Belanger \& Slyke, 2002); (2) Recovery behavior. This behavior assumes that employee cyberloafing behavior can reduce discomfort and provide positive effects for employees and organizations (McLean, Tingley, Scott \& Richards, 2001; Lim \& Chen, 2009); (3) Deviant behavior. This behavior assumes that cyberloafing behavior is a distortion of unwanted behavior and is directed at the organization; (4) Addiction behavior. Cyberloafing behavior in this context is considered as a habit that leads to the emergence of problematic behavior.

Research on cyberloafing behavior in the workplace has been widely carried out. Nevertheless, the development of studies related to cyberloafing behavior still requires development. Research development is carried out because the effects caused by cyberloafing behavior on emotions, cognitions and employee behavior can have negative impacts (Lim \& Chen, 2012; Malhotra, 2013). It was stated by Lim (2002), Johnson \& Indvik (2003), Henle \& Blanchard (2008), Bock, Shin, Liu \& Sun (2010) that studies related to cyberloafing behavior are often only associated with negative consequences. Declining productivity (Beugre \& Kim, 2006; Weatherbee, 2010; Liberman et al., 2011; Malhotra, 2013), increasing costs of corporate internet use (Beugre \& Kim, 2006; Liberman et al., 2011; Malhotra, 2013), increasing indiscipline (Weatherbee, 2010; Malhotra, 2013) is a negative outcome of cyberloafing that is widely expressed in various studies.

\section{Hypothesis Development}

Effect of Job Characteristics on Job Stress and Cyberloafing

Job characteristics are related to the characteristics of the work carried out by employees in the company which includes skill variety/job (skill variety), job identity (task identity), job significance (task significance), autonomy (autonomy) and feedback (feedback). If employees experience skill variety, task identity, task significance, autonomy and feedback, employees experience job stress and cyberloafing behavior.

Based on the description above, the following hypothesis was developed:

H1: Job Characteristics have a positive effect on job stress

H2: Job Characteristics have a positive effect on cyberloafing

H3: Job stress has a positive effect on cyberloafing.

\section{The Effect of Self Control on Cyberloafing}

Self control is related to the individual ability of employees to control or control their behavior within the organization. Studies on the effect of self-control on cyberloafing behavior have been studied by several previous researchers. A study conducted by Sari \& Ratnaningsih (2018) shows that selfcontrol is able to explain the variation in cyberloafing behavior negatively. However, the study conducted by Ramadhan \& Sari (2018) shows a different direction where selfcontrol explains cyberloafing behavior positively.

Based on the description above, the following hypothesis was developed:

H4: Self control has a negative effect on cyberloafing

\section{The Effect of Cyberloafing on Laziness}

In this behavior, cyberloafing has negative consequences for the organization (such as decreased productivity) (Weatherbee, 2010; Young, 2010). Yellowlees \& Marks (2007) revealed that severe internet addiction will lead to problems in work behavior. More specifically, Stanton (2002) and Yellowlees \& Marks (2007) show that the consequences of Internet addiction can lead to decreased performance.

Based on the description above, the following hypothesis was developed:

H5: Cyberloafing has a positive effect on laziness 


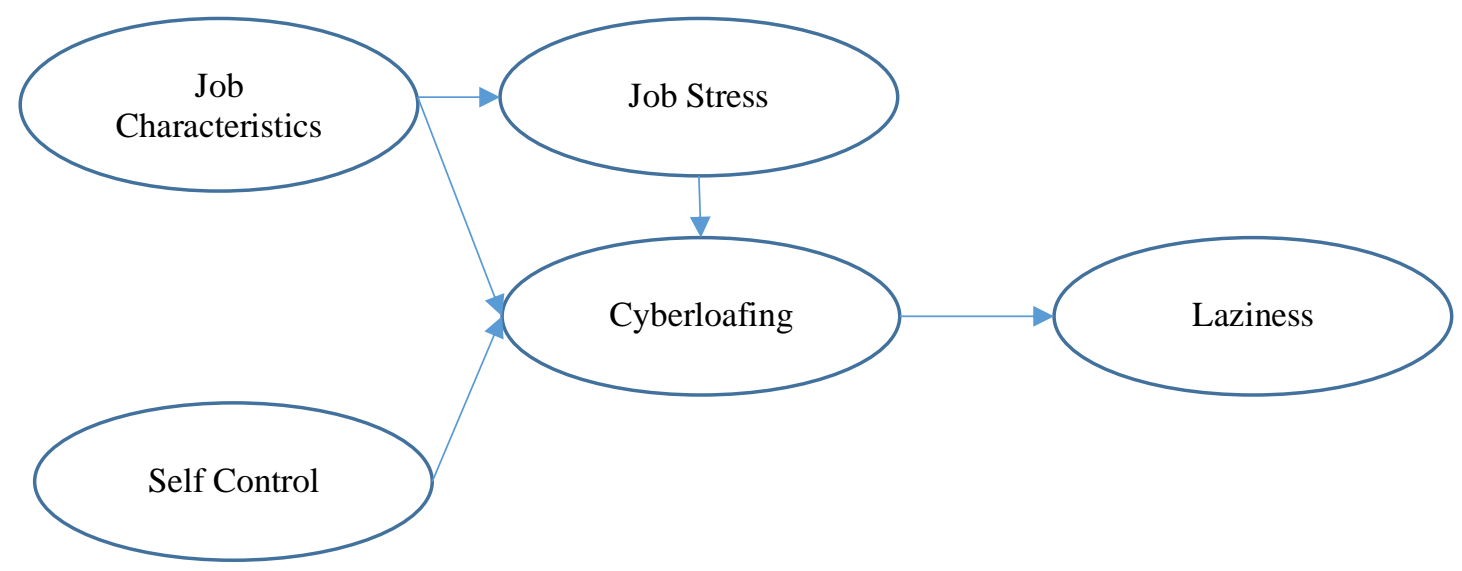

Figure 1. Empirical Model

Source: Developed for this study (2019)

Differences in Cyberloafing Behavior Models Affect Laziness on Female and Male Employees

The study of Kim and Davis (2009) showed a preference for the use of the internet by women for the reasons of seeking information, establishing relationships and for shopping purposes. While the use of the internet in men for reasons to be able to have relationships with people from all over the world and to get a job. A study conducted by Garrett \& Danziger (2008) found differences in the use of the internet for personal reasons, pleasure and communication based on gender.

The comparative study on cyberloafing behavior preferences conducted by Lim \& Chen (2012) showed different results. In his study, men tend to do more cyberloafing than women. Although some literature has tested differences in internet use preferences by gender, these results are not conclusive.

Women assume that using the internet will get a wide social network. Meanwhile, men use the internet for relaxation reasons or to show their strength (Colley \& Maltby, 2008; Garrett \& Danziger, 2008).

Based on the description above, the following hypothesis was developed:

H6: The cyberloafing behavior model affects laziness in male employees differently than female employees

\section{Empirical Model}

Effect between research variables was visualized in an empirical model developed and tested in this study.

\section{Research Method}

\section{Population and Sample}

The population studied in this study were company employees from several industries. The industries studied in this study were: automotive, education, banking, garment and pharmaceutical.

Based on the results of data collection, a sample of 228 respondents was obtained with the distribution of the number of samples used in this study as follows:

Table 2. Distribution of Samples for Each Industry

\begin{tabular}{clcc}
\hline \multirow{2}{*}{ No. } & \multirow{2}{*}{ Industry } & \multicolumn{2}{c}{ Sample } \\
\cline { 3 - 4 } & & Men & Women \\
\hline 1. & Automotive & 35 & 12 \\
2. & Education & 27 & 31 \\
3. & Banking & 25 & 31 \\
4. & Garment & 15 & 25 \\
5. & Pharmacy & 12 & 15 \\
\hline & Total & $\mathbf{1 1 4}$ & $\mathbf{1 1 4}$ \\
\hline
\end{tabular}

Source: Developed for this study, 2019

\section{Data collection}

Data was collected through interviews using interview guides that had been prepared. The interview guide contains statement items which are measurements of the variables studied. Respondents were asked to answer 
statements in accordance with the conditions at the time of the research done by providing variables, this study used Structural Equation Modeling (SEM) as a data analysis tool.

Table 3. Operationalization of Research Variables

\begin{tabular}{|c|c|c|c|}
\hline Variable & & Indicators & Source \\
\hline Job & $\mathrm{X} 1$ & Skill variety & Arshad, Aftab \& Bukhari \\
\hline Characteristic & $\mathrm{X} 2$ & Task identity & $(2016)$ \\
\hline & $\mathrm{X} 3$ & Task significance & \\
\hline & $\mathrm{X} 4$ & Autonomy & \\
\hline & $\mathrm{X} 5$ & Feedback & \\
\hline Self-control & $\mathrm{X} 6$ & impulsiveness & Gottfredson \& Hirschi \\
\hline & $\mathrm{X} 7$ & preference for physical activity & (1990), Ramadhan \& Sari \\
\hline & $\mathrm{X} 8$ & risk-seeking orientation & (2018), Ardilasari \& \\
\hline & X9 & self-centeredness & Firmanto (2017) \\
\hline & $\mathrm{X} 10$ & preference for simple tasks & \\
\hline & $\mathrm{X} 11$ & short-tempered & \\
\hline Work Stress & $\mathrm{X} 12$ & experiencing digestive disorders & Rahmawati (2010), \\
\hline & $\mathrm{X} 13$ & headaches caused by the workload & Kusumawati \& Fransiska \\
\hline & $\mathrm{X} 14$ & feeling desperate while working & $(2018)$ \\
\hline & $\mathrm{X} 15$ & easy to be offended & \\
\hline & $\mathrm{X} 16$ & difficult to concentrate & \\
\hline & $\mathrm{X} 17$ & like to procrastinate & \\
\hline & $\mathrm{X} 18$ & feeling bored with work & \\
\hline & X19 & feeling anxious at work & \\
\hline & $\mathrm{X} 20$ & less satisfied with work & \\
\hline & $\mathrm{X} 21$ & lack of enthusiasm in work & \\
\hline & $\mathrm{X} 22$ & unhappy following office activities & \\
\hline Cyberloafing & $\mathrm{X} 23$ & $\begin{array}{l}\text { receiving or checking or sending personal } \\
\text { emails }\end{array}$ & Lim \& Chen (2012) \\
\hline & $\mathrm{X} 24$ & $\begin{array}{l}\text { accessing websites that are not related to } \\
\text { work (news, sports, entertainment / } \\
\text { entertainment) }\end{array}$ & \\
\hline & $\mathrm{X} 25$ & sending Private messages & \\
\hline & $\mathrm{X} 26$ & downloading non-work related information & \\
\hline & $\mathrm{X} 27$ & online shopping & \\
\hline & $\mathrm{X} 28$ & searching for job vacancies & \\
\hline & $\mathrm{X} 29$ & playing online games & \\
\hline Laziness & $\mathrm{X} 30$ & working slowly & Developed for this research \\
\hline & $\mathrm{X} 31$ & Grumbling & \\
\hline & $\mathrm{X} 32$ & lingering with the internet & \\
\hline & $\mathrm{X} 33$ & delaying starting work & \\
\hline
\end{tabular}

responses to closed answers on a scale of 1-10 that was provided.

\section{Operationalization of Research Variables}

Operationalization of variables is needed for the purpose of measuring research variables. Operationalization of variables was done by setting indicators adopted from the results of previous relevant studies.

\section{Analysis Techniques}

For the sake of testing the research model and testing the effect between the research

\section{Result and Discussion}

There were two analysis processes carried out in this study, namely research model testing and comparative testing. The process of the two tests is described below:

\section{Research Model Testing}

Empirical models and the effect between variables developed in this study used Structural Equation Modeling (SEM) as an analytical technique approach. In SEM there are two stages of testing carried out. These stages are described below. 


\section{Confirmatory Analysis}

Confirmatory analysis is the stage carried out to confirm the accuracy of the indicators in measuring the research variables. There are two outputs used as a reference in measuring the accuracy of indicators, namely by analyzing the value of Standardized Regression Weight which is presented in the following table:

Table 4. Confirmatory Analysis Output

\begin{tabular}{|c|c|c|c|}
\hline Variable & Indicator & $\begin{array}{c}\text { Standardized } \\
\text { Reg Weight }\end{array}$ & Conlusion \\
\hline Job & $\mathrm{X} 1$ & 0.752 & Accepted \\
\hline \multirow[t]{4}{*}{ Characteristics } & $\mathrm{X} 2$ & 0.713 & Accepted \\
\hline & $\mathrm{X} 3$ & 0.702 & Accepted \\
\hline & $\mathrm{X} 4$ & 0.707 & Accepted \\
\hline & $\mathrm{X} 5$ & -0.032 & Rejected \\
\hline \multirow[t]{6}{*}{ Self-control } & X6 & 0.166 & Rejected \\
\hline & $\mathrm{X} 7$ & 0.730 & Accepted \\
\hline & $\mathrm{X} 8$ & 0.761 & Accepted \\
\hline & X9 & 0.728 & Accepted \\
\hline & $\mathrm{X} 10$ & 0.620 & Accepted \\
\hline & $\mathrm{X} 11$ & 0.614 & Accepted \\
\hline \multirow[t]{11}{*}{ Work stress } & $\mathrm{X} 12$ & 0.289 & Rejected \\
\hline & $\mathrm{X} 13$ & 0.321 & Rejected \\
\hline & X14 & 0.285 & Rejected \\
\hline & $\mathrm{X} 15$ & 0.698 & Accepted \\
\hline & X16 & 0.679 & Accepted \\
\hline & $\mathrm{X} 17$ & 0.743 & Accepted \\
\hline & $\mathrm{X} 18$ & 0.755 & Accepted \\
\hline & X19 & 0.726 & Accepted \\
\hline & $\mathrm{X} 20$ & 0.645 & Accepted \\
\hline & $\mathrm{X} 21$ & 0.121 & Rejected \\
\hline & $\mathrm{X} 22$ & 0.188 & Rejected \\
\hline \multirow[t]{7}{*}{ Cyberloafing } & $\mathrm{X} 23$ & 0.793 & Accepted \\
\hline & $\mathrm{X} 24$ & 0.733 & Accepted \\
\hline & $\mathrm{X} 25$ & 0.778 & Accepted \\
\hline & $\mathrm{X} 26$ & 0.726 & Accepted \\
\hline & $\mathrm{X} 27$ & 0.673 & Accepted \\
\hline & $\mathrm{X} 28$ & 0.033 & Rejected \\
\hline & X29 & -0.010 & Rejected \\
\hline \multirow[t]{4}{*}{ Creativity } & $\mathrm{X} 30$ & 0.741 & Accepted \\
\hline & X31 & 0.752 & Accepted \\
\hline & X32 & 0.849 & Accepted \\
\hline & X33 & 0.765 & Accepted \\
\hline \multirow[t]{4}{*}{ Laziness } & X34 & 0.774 & Accepted \\
\hline & X35 & 0.851 & Accepted \\
\hline & X36 & 0.861 & Accepted \\
\hline & X37 & 0.727 & Accepted \\
\hline
\end{tabular}

Referring to the results of the confirmatory analysis presented in the Table above, the indicators that produce a Standardized Regression Weight below 0.5 are declared null because they cannot statistically reflect measurements on the research variable.

\section{Hypothesis Testing}

At this stage, there are two tests conducted, namely testing the serviceability of the research model and testing the research hypothesis.

The following is an evaluation of the empirical model testing developed in this study.

\begin{tabular}{cccc}
\multicolumn{4}{c}{ Tabel 5 Goodness of Fit Model } \\
\hline $\begin{array}{c}\text { Goodness of Fit } \\
\text { Indeks }\end{array}$ & $\begin{array}{c}\text { Cut off } \\
\text { Value }\end{array}$ & Hasil & Kesimpulan \\
\hline $\begin{array}{c}\text { Chi-Square }(\mathrm{df}= \\
\text { 246) }\end{array}$ & $<$ & 262,043 & Good \\
Probability & $\geq 0.05$ & 0,230 & Good \\
CMIN/DF & $\leq 2.00$ & 1,065 & Good \\
GFI & $\geq 0.90$ & 0,918 & Good \\
AGFI & $\geq 0.90$ & 0,900 & Good \\
TLI & $\geq 0.95$ & 0,991 & Good \\
CFI & $\geq 0.95$ & 0,992 & Good \\
RMSEA & $\leq 0.08$ & 0,017 & Good \\
\hline
\end{tabular}

Source: Primary Data Processed, 2020

The empirical model testing developed in this study produced a Chi Square value of 262,043 and a probability value of 0,230 . The Chi Square value is smaller than the Chi Square table value $(283,585)$ with a probability value greater than 0,05 so that it can be concluded that the research model is the right model.

After testing the feasibility of the model, it can be tested for the effect of the variables presented in the Table 6.

Testing the effect between variables was done by analyzing the probability value and the value of the Critical Ratio (CR). The probability value in job characteristics and work stress testing was $0,008<0,05$ and CR was 2,674 , meaning that the job characteristics

Table 6. Hypothesis Testing

\begin{tabular}{lllrrrrr}
\hline & & Std Estimate & Estimate & S.E. & C.R. & P \\
\hline Work_Stress & $<---$ & Job_Characteristic &, 220 &, 291 &, 109 & 2,674 &, 008 \\
Cyberloafing & $<--$ & Work_Stress &, 238 &, 306 &, 110 & 2,793 &, 005 \\
Cyberloafing & $<---$ & Self_Control & -193 &,- 255 &, 110 & $-2,309$ &, 021 \\
Cyberloafing & $<---$ & Job_Characteristic &,- 003 &,- 005 &, 135 &,- 039 &, 969 \\
Laziness & $<---$ & Cyberloafing &, 155 &, 157 &, 078 & 2,013 &, 044 \\
\hline
\end{tabular}


statistically had a positive significant effect in explaining work stress.
$\mathrm{CR}$ was $-0,039$, meaning that job characteristics statistically had a negative non

Table 7. Results of Goodness of Fit Testing of Research Models Based on Gender

\begin{tabular}{lccccc}
\hline \multirow{2}{*}{$\begin{array}{c}\text { Goodness of Fit } \\
\text { Indeks }\end{array}$} & $\begin{array}{c}\text { Cut off } \\
\text { Value }\end{array}$ & Result & $\begin{array}{c}\text { Model } \\
\text { Evaluation }\end{array}$ & Hasil & $\begin{array}{c}\text { Model } \\
\text { Evaluation }\end{array}$ \\
\cline { 3 - 6 } & $<283,585$ & 242,106 & Good & 261,496 & Good \\
Chi-Square & $\geq 0,05$ & 0,558 & Good & 0,238 & Good \\
Probability & $\leq 2,00$ & 0,984 & Good & 1,063 & Good \\
CMIN/DF & $\geq 0,90$ & 0,862 & Marginal & 0,855 & Marginal \\
GFI & $\geq 0,90$ & 0,832 & Marginal & 0,823 & Marginal \\
AGFI & $\geq 0,95$ & 1,005 & Good & 0,986 & Good \\
TLI & $\geq 0,95$ & 1,000 & Good & 0,987 & Good \\
CFI & $\leq 0,08$ & 0,000 & Good & 0,024 & Good \\
RMSEA &
\end{tabular}

Source: Primary Data, Processed (2019)

Probability value in work stress and cyberloafing testing was $0,005<0,05$ and $\mathrm{CR}$ was 2,793, meaning that work stress statistically had a positive significant effect in explaining cyberloafing.

Probability value in self-control and cyberloafing testing was $0,021<0.05$ and CR was $-2,309$, meaning that self-control statistically had a negative significant c.effect in explaining cyberloafing.

Probability value in job characteristics and cyberloafing testing was $0,969>0,05$ and significant effect in explaining cyberloafing.

Probability value in cyberloafing and laziness testing was $0,044<0,05$ and CR was 2,013, meaning that cyberloafing had a statistically a positive effect in explaining laziness.

\section{Comparative Testing}

Comparative testing is a test carried out to determine differences in research models and the effect of variables based on gender.

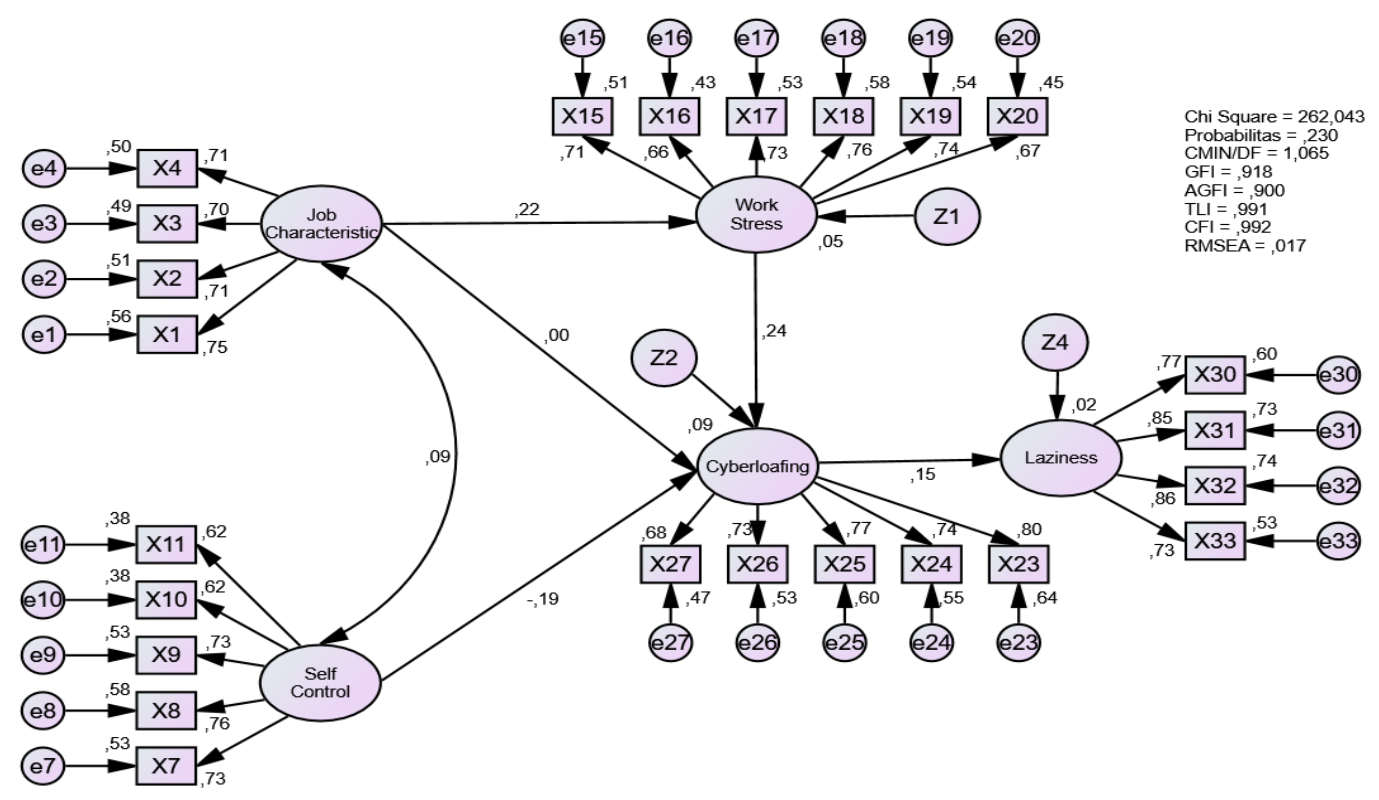

Figure 2. Results of Research Model Testing 
Table 8. Hypothesis Testing Based on Gender

\begin{tabular}{|c|c|c|c|c|c|c|c|c|c|c|}
\hline \multirow{2}{*}{\multicolumn{3}{|c|}{ Effect Between Variables }} & \multicolumn{4}{|c|}{ Men } & \multicolumn{4}{|c|}{ Woman } \\
\hline & & & \multirow{2}{*}{$\begin{array}{r}\begin{array}{r}\text { Std. } \\
\text { Estimate }\end{array} \\
, 220\end{array}$} & \multirow{2}{*}{$\begin{array}{c}\text { C.R. } \\
1,823\end{array}$} & \multirow{2}{*}{$\frac{\mathbf{P}}{, 068}$} & \multirow{2}{*}{\begin{tabular}{l}
\multicolumn{1}{r}{ Finding } \\
Not \\
significant
\end{tabular}} & \multirow{2}{*}{$\begin{array}{r}\begin{array}{r}\text { Std. } \\
\text { Estimate }\end{array} \\
, 237\end{array}$} & \multirow{2}{*}{$\begin{array}{r}\text { C.R. } \\
2,095\end{array}$} & \multirow{2}{*}{$\begin{array}{r}\mathbf{P} \\
, 036\end{array}$} & \multirow{2}{*}{$\begin{array}{r}\text { Finding } \\
\text { Significant }\end{array}$} \\
\hline Work_Stress & $\leftarrow$ & $\begin{array}{l}\text { Job } \\
\text { Characteristic }\end{array}$ & & & & & & & & \\
\hline Cyberloafing & $\leftarrow$ & Work_Stress & ,319 & 2,509 &, 012 & Significant & , 199 & 1,719 & ,086 & $\begin{array}{l}\text { Not } \\
\text { significant }\end{array}$ \\
\hline Cyberloafing & $\leftarrow$ & Self_Control &,- 206 & $-1,729$ & ,084 & $\begin{array}{l}\text { Not } \\
\text { significant }\end{array}$ &,- 187 & $-1,607$ &, 108 & $\begin{array}{l}\text { Not } \\
\text { significant }\end{array}$ \\
\hline Cyberloafing & $\leftarrow$ & $\begin{array}{l}\text { Job } \\
\text { Characteristic }\end{array}$ &,- 056 &,- 471 & ,638 & $\begin{array}{l}\text { Not } \\
\text { significant }\end{array}$ &, 025 &, 230 &, 818 & $\begin{array}{l}\text { Dit Not } \\
\text { significant } \\
\text { olak }\end{array}$ \\
\hline Laziness & $\leftarrow$ & Cyberloafing & ,099 & ,886 & ,376 & $\begin{array}{l}\text { Not } \\
\text { significant }\end{array}$ &, 195 & 1,821 & ,069 & $\begin{array}{l}\text { Not } \\
\text { significant }\end{array}$ \\
\hline
\end{tabular}

Source: Primary Data, Processed (2019)

Table 7 showed that the Chi Square value for each group was smaller than the critical Chi Square value as well as a significance value greater than 0,05 . These results indicated that there was no difference between the sample covariance matrixes with the estimated population covariance matrix or in other words the model was accepted or fit.

This subsection provides an explanation of the effect between variables based on each gender group.

The results of testing the effect between variables based on gender groups showed that in men, work stress had a significant positive effect on cyberloafing. It means the higher work stress experienced by male employees will increase cyberloafing. Male employees become happy to linger surfing in cyberspace during work hours. But different in the findings produced by female employees, stress did not actually cause cyberloafing. The results of testing the effect on women's groups indicated that the increase in cyberloafing was caused by the increasing characteristics of work. This test also showed that cyberloafing by female employees can in fact increase creativity.

\section{Conclusion}

Empirical phenomena indicated that cyberloafing conducted by employees during working hours by using internet facilities provided by the company is getting higher. Cyberloafing carried out was indicated to have no relevance to the work process. Some previous studies mention many factors that trigger the increasing cyberloafing with the results of studies that are not yet conclusive. In addition, previous research also has not conducted empirical testing of the effects arising from cyberloafing. From these findings, this study developed a comprehensive research model by examining variables at the organizational level, namely the job characteristics and variables at the individual level, namely self-control as a cyberloafing explanation. This study also seeks to empirically examine cyberloafing outcomes both positively and negatively.

The results of overall model tests showed that there was a real effect of job characteristics, work stress and self-control in explaining cyberloafing. Furthermore, this study also found that cyberloafing could trigger creativity and laziness in employees. However, comparative testing based on gender showed that in male employees, cyberloafing was only explained by work stress while in female employees it was explained by job characteristics. Outcome from cyberloafing was only obtained for female employees where in fact cyberloafing could increase the creativity of female employees.

\section{Daftar Referensi}

Abidin, R., Abdullah C.S, Hasnan N \& Bajuri A.L (2014). The Relationship of Cyberloafing Behavior with Big Five Personality Traits. Australian Journal of Basic and Applied Science, 8 (12), 6166. 
Al-Shuaibi, Ahmad Said \& Faridahwati Mohd Shamsudin, Chandrakantan Subramanian (2013). Do Human Resource Management Practices Matter in Reducing Cyberloafing at Work: Evidence from Jordan. Journal of WEI Business and Economics, 2 (2), 1-11.

Anandarajan, M., N. Paravastu \& C. Simmers (2006). Perceptions of Personal Web Usage in the Workplace: AQMethodology Approach. Cyberpsychology and Behavior, 9 (3), 325-335.

Anandarajan, M., C. Simmers, \& M. Igbaria (2000). An Exploratory Investigation of The Antecedents and Impact of Internet Usage: An Individual Perspective. Behaviour and Information Technology, 19 (1), 69-85.

Ardilasari, Noratika \& Ari Firmanto (2017). Hubungan Self Control dan Perilaku Cyberloafing pada Pegawai Negeri Sipil. Jurnal Ilmiah Psikologi Terapan, 5 (1), 19-39.

Arshad, Madiha., Muhammad Aftab \& Hifza Bukhari (2016). The Impact of Job Characteristics and Role Stressors on Cyberloafing: The Case of Pakistan. International Journal of Scientific and Research Publication, 6 (12), 244-252.

Baumeister, R.F (2002). Handbook of Social Psychology, McGraw-Hill, New York.

Belanger, F \& C Van Slyke (2002). Abuse or Learning?. Communications of the ACM, 45 (1), 617-638.

Beugre, C.D \& D. Kim (2006). Cyberloafing: Vice or Virtue, Emerging Trends and Challenges in Information Technology Management.

Blancard, AL \& CA Henle (2008). Correlates of Different Form of Cyberloafing: The Role of Norms and External Locus of Control. Computers in Human Behavior, 24, 1067-1084.

Block, W (2001). Cyberslacking, Business Ethics and Managerial Economics. Journal of Business Ethics, 33, 225-231.
Bock, G., Y. Shin, P. Liu \& H. Sun (2010). The Role of Task Characteristics and Organisational Culture in Non-WorkRelated Computing: A Fit Perspective. Advances in Information Systems, 41 (2), 132-151.

Colley, A \& J. Maltby (2008). Impact of the Internet on Our Lives: Male and Female Personal Perspectives. Computers in Human Behaviour, 24, 2005-2013.

Garrett, R Kelly \& James N Danziger (2008a). Disaffection or Expected Outcomes: Understanding Personal Internet Use During Work. Journal of ComputerMediated Communication, 13, 937-958.

Garrett, R Kelly \& James N Danziger (2008b). On Cyberslacking: Workplace Status and Personal Internet Use at Work. Cyberpsychology \& Behavior, 11, 287292.

Griffiths, M (2010). Internet Abuse and Internet Addiction in The Workplace. Journal of Workplace Learning, 22 (7), 463-472.

Henle, CA \& AL Blancard (2008). The Interaction of Work Stressor and Organizational Sanction on Cyberloafing. Journal of Managerial Issues, 20, 383-400.

Johnson, P.R \& J. Indvik (2003). The Organisational Benefits of Reducing Cyberslacking in The Workplace. Communications and Conflict, 7 (2), 53 59.

Kim, H \& K.E Davis (2009). Toward a Comprehensive Theory of Problematic Internet Use: Evaluating the Role of Self-Esteem, Anxiety, Flow, and The Self-Rated Importance of Internet Activities. Computers in Human Behaviour, 25, 490-500.

Koay, Kian Yeik., Patrick Chin-Hooi Soh \& Kok Wai Chew (2017). Do Employees's Private Demands Lead to Cyberloafing? The Mediating Role of Job Stress. Management Research Review, 40 (9), 1025-1038. 
Kusumawati, Aqsa \& Rosaly Fransiska (2018). Work-Family Conflict and Cyberloafing: The Mediating Role of Work Stress. Diponegoro International Journal of Business, 1 (2), 86-93.

Liberman, B., G. Seidman, K.Y.A McKenna, \& L.E Buffardi (2011). Employee Job Attitudes and Organizational Characteristics as Predictors of Cyberloafing. Computers in Human Behavior, 27, 2192-2199.

Lim, V.K.G \& D.J.O Chen (2009). Cyberloafing at The Workplace: Gain or Drain on Work? Behaviour \& Information Technology, 1-11.

Lim, V.K.G \& T.S.H Teo (2005). Prevalence, Perceived Seriousness, Justification and Regulation of Cyberloafing in Singapore: an Exploratory Study. Information and Management, 42, 10811093.

Lim, V (2002). The IT Way of Loafing on The Job: Cyberloafing, Neutralizing and Organizational Justice. Journal of Organizational Behavior, 23 (5), 675694.

Lim, Vivien K.G \& Don Jiaqing Chen (2012). Cyberloafing at The Workplace: Gain or Drain on Work? Behavior and Information Technology, 31 (4), 343353.

Lynn, B., S. Coker \& B.L.S Coker (2011). Freedom to Surf : The Positive Effects of Workplace Internet Leisure Browsing. New Technology, Work, and Employment, 26 (3), 238-247.

Malhotra, S (2013). Cyberloafing a Holistic Perspective, An Online Interdisciplinary. Multidisciplinary dan Multi-cultural Journal, 2.

McLean, L., M. Tingley, R.N Scott \& J. Richards (2001). Computer Terminal Work and The Benefit of Micro Breaks. Applied Ergonomics, 32, 225-237.

Ono, H \& M. Zavodny (2003). Gender and the Internet. Social Science Quarterly, 84 (1), 111-121.
Oravec, J.A (2002). Constructive Approaches to Internet Recreation in The Workplace. Communications of the Acm, 45, 60-63.

Ozler, Derya Ergun \& Gulcin Polat (2012). Cyberloafing Phenomenon in Organizations: Determinants and Impacts. International Journal of eBusiness and eGovernment Studies, 4 (2), 2146-0744.

Ramadhan, Vian Arsita \& Erita Yuliaseti Diah Sari (2018). Perilaku Cyberloafing pada Pekerja Perempuan. Jurnal Psikologi Integratif, 6 (2), 213-224.

Robbins, Stephen \& T.A Judge (2008). Perilaku Organisasi. Jakarta: Salemba Empat.

Salleh, A.L., R.A Bakar \& W.K Keong (2008). How Detrimental is Job Stress? : A Case Study Of Executives in the Malaysian Furniture Industry. International Review of Business Research Papers, 4 (5).

Sari, Suci Laria \& Ika Zenita Ratnaningsih (2018). Hubungan antara Kontrol Diri dengan Intensi Cyberloafing pada Pegawai Dinas X Provinsi Jawa Tengah. Jurnal Empati, 7 (2), 160-166.

Seymour, L \& K. Nadasen (2007). Web Access for IT Staff: A Developing World Perspective on Web Abuse. The Electronic Library, 25 (5), 543-557.

Stanton, J.M (2002). Company Profile of The Frequent Internet User. Communications of the ACM, 45, 55-59.

Wasian, Gretiano (2019). Dampak Internet Tanpa Batas di Dunia Kerja: Cyberloafing. Buletin Jagaddhita, Januari.

Weatherbee, T.G (2010). Counterproductive Use of Technology at Work: Information \& Communications Technologies and Cyberdeviancy. Human Resource Management Review, 20 (1), 35-44.

Yellowlees, P.M \& S. Marks (2007). Problematic Internet use or Internet addiction?. Computers in Human Behaviour, 23, 1447-1453. 
Young, K (2010). Policies and Procedures to Manage Employee Internet abuse.
Computers in Human Behavior, 26 (6), 1467-1471. 